\title{
PELATIHAN METODE PEMBELAJARAN MASAK (MUDAH, ASYIK, SANTAI, AKTIF, KREATIF) TERHADAP PENGUASAAN KOSAKATA DAN MENDENGARKAN BAHASA INGGRIS GURU PAUD RA BINTANG SEMBILAN CIPAYUNG DEPOK
}

\author{
Sugianti Somba $^{1)}$, Ria Saraswati ${ }^{2)}$ \\ ${ }^{1,2}$ Program Studi Pendidikan Bahasa Inggris, Fakultas Bahasa dan Seni, \\ Universitas Indraptasta PGRI
}

\begin{abstract}
Abstrak
Pembelajaran adalah proses interaksi antar anak didik antara anak didik dan pendidik dengan melibatkan orang tua serta sumber belajar pada suasana belajar dan bermain di satuan atau program PAUD. Kegiatan pembelajaran pada anak usia dini pada dasarnya adalah pengembangan kurikulum dan rencana konkret yang berisi sejumlah pengalaman belajar dengan metode bermain yang diberikan kepada anak usia dini dalam rangka pencapaian kompetensi yang harus diberikan kepada anak. Metode pembelajaran yang bisa digunakan dalam pengajaran bahasa Inggris di TK adalah metode pembelajaran MASAK (Mudah, Asyik, Santai, Aktif, Kreatif). Hal ini bertujuan menumbuhkan keberanian anak dalam berekspresi dalam bahasa Inggris sehingga anak tertarik pada kegiatan pembelajaran yang berlangsung. Model pembelajaran MASAK ini mengajak anak untuk langsung berinteraksi dengan temannya, melakukan tindakan, serta merupakan kegiatan yang menyenangkan, sehingga anak akan mudah mengingat vocab atau kosakata. Peran seorang guru dalam menyediakan media pembelajaran yang menarik serta mudah dimengerti anak sangat diperlukan. Secara eksplisit, kegiatan ini bertujuan untuk menjelaskan prosedur dan manfaat penerapan Metode pembelajaran MASAK) dalam pembelajaran kosa kata dan kemampuan berbicara bahasa Inggris kepada Guru PAUD RA Bintang Sembilan Cipayung, Depok. Dari hasil pelaksanaan kegiatan pengabdian kepada masyarakat, diberikan beberapa kesimpulan sebagai berikut: (1) Metode MASAK (Mudah, Asyik, Santai, Aktif, Kreatif) merupakan salah satu metode yang tepat untuk digunakan dalam mengajarkan Bahasa Inggris, terutama kosakata dan mnyimak kepada anak dengan cara yang menyenangkan dan mudah. (2) Guru dapat memanfaatkan penggunaan metode MASAK (Mudah, Asyik, Santai, Aktif, Kreatif) dalam menyampaikan pembelajaran mengenai penguasaan kosakata bahasa Inggris. (3) Sekolah dapat memanfaatkan metode MASAK untuk menunjang pembelajaran sehingga dapat meningkatkan kualitas pembelajaran dan menghasilkan pembelajaran yang berkualitas.
\end{abstract}

Kata kunci: pembelajaran, MASAK, berkualitas

\begin{abstract}
Learning is the process of interaction between students between students and educators by involving parents and learning resources in the atmosphere of learning and playing in PAUD units or programs. Learning activities in early childhood are essentially concrete curriculum development in the form of a set of plans that contain a number of learning experiences through play given to early childhood based on the potential and developmental tasks that must be mastered in order to achieve the competencies that must be possessed by children. Learning methods that can be used in teaching English in kindergarten are MASAK learning methods (Easy, Fun, Casual, Active, Creative). It aims to foster children's courage in expression in English so that children are interested in ongoing learning activities. The MASAK learning model invites children to directly interact with their friends, take action, and is a fun activity, so that children will easily remember vocab or vocabulary. The role of a teacher in providing learning media that is interesting and easy for children to understand is needed. Explicitly, this activity aims to explain the
\end{abstract}


procedures and benefits of applying the MASAK learning method in vocabulary learning and English speaking skills to the teachers PAUD RA Bintang Sembilan Cipayung, Depok. From the results of the implementation of community service activities, several conclusions are given as follows: (1) The COOK Method (Easy, Fun, Casual, Active, Creative) is one of the right methods to be used in teaching English, especially vocabulary and listening to children with fun and easy way. (2) Teachers can utilize the use of the COOK method in conveying learning about mastering English vocabulary. (3) Schools can utilize the COOK method to support learning so as to improve the quality of learning and produce quality learning.

Key word : Learning, MASAK, Qualified

Correspondence author: Sugianti Somba, sugianti.somba@gmail.com, Jakarta, Indonesia.

This work is licensed under a CC-BY-NC

\section{PENDAHULUAN}

Di Indonesia, pembelajaran bahasa Inggris untuk anak usia dini belum terdapat dalam kurikulum, mengingat memang pada tahap usia ini anak masih baru belajar tentang bahasa Ibu. Menurut para pakar, anak berusia 6-12 tahun memiliki daya pikir yang sangat baik sehingga kemampuan penyerapan bahasa kedua berfungsi secara otomatis (Izdihar, 2009:4). Akan tetapi tidak ada salahnya jika bahasa Inggris mulai dikenalkan pada usia dini dengan cara yang menyenangkan dan tetap memperhatikan perkembangan anak. Mengajarkan lebih dari satu Bahasa kepada anak-anak tidaklah mudah, sebagai contoh ketika mengajarkan Bahasa Inggris. Apalagi jika di lingkungan mereka tidak menggunakan Bahasa Inggris sebagai alat komunikasi. Selain itu perlu dipahami betul konsekuensi dari pilihan menggunakan lebih dari satu bahasa dengan anak sehingga penerapannya membawa dampak yang positif bagi perkembangan anak dan bukan sebaliknya.

Tugas guru sebagai profesi meliputi mendidik, mengajar dan melatih. Mendidik bermakna meneruskan dan mengembangkan nilai-nilai kehidupan. Mengajar bermakna meneruskan dan mengembangkan ilmu pengetahuan dan teknologi. Sedangkan melatih bermakna mengembangkan berbagai keterampilan pada siswa. Untuk mendidik, mengajar, dan melatih seorang guru tentunya memerlukan metode pembelajaran yang notabene merupakan bagian terpenting dalam melaksanakan proses belajar. Pembelajaran sebaiknya dilaksanakan dengan cara menarik yang mampu membangkitkan minat siswa untuk melaksanakan pembelajaran. Pembelajaran adalah proses interaksi antar anak didik antara anak didik dan pendidik dengan melibatkan orang tua serta sumber belajar pada suasana belajar dan bermain di satuan atau program PAUD (Permendikbud, Pasal 1:13).

Metode pembelajaran yang bisa digunakan dalam pengajaran bahasa Inggris di TK adalah metode pembelajaran MASAK (Mudah, Asyik, Santai, Aktif, Kreatif). MASAK (Mudah, Asyik, Santai, Aktif, Kreatif) adalah metode pembelajaran dengan lingkungan yang menyenangkan dengan menggunakan gerakan tubuh, tindakan, dan gambar, dengan cara seperti ini pengetahuan anak akan terbangun dengan menggunakan imajinasi mereka berdasarkan tanda-tanda di sekitar lingkungannya. Menumbuhkan keberanian anak dalam berekspresi dalam bahasa Inggris sehingga anak tertarik pada kegiatan pembelajaran yang berlangsung. Model pembelajaran MASAK (Mudah, 
Asyik, Santai, Aktif, Kreatif) ini mengajak anak untuk langsung berinteraksi dengan temannya, melakukan tindakan, serta merupakan kegiatan yang menyenangkan, sehingga anak akan mudah mengingat vocab atau kosakata. Peran seorang guru dalam menyediakan media pembelajaran yang menarik serta mudah dimengerti anak sangat diperlukan.

Secara eksplisit, kegiatan ini bertujuan untuk menjelaskan prosedur dan manfaat penerapan Metode pembelajaran MASAK (Mudah, Asyik, Santai, Aktif, Kreatif) dalam pembelajaran kosa kata dan kemampuan berbicara bahasa Inggris kepada Guru PAUD RA Bintang Sembilan Cipayung, Depok.

RA Bintang Sembilan merupakan lembaga Pendidikan Anak Usia Dini (PAUD) yang terletak di Jambu Tree Residence R.7, Jalan Raya Citayam, Cipayung, Pondok Jaya, Kota Depok. Visi lembaga pendidikan ini adalah memupuk generasi yang cerdas dan saleh. Dengan demikian kompetensi dasar yang harus dimiliki peserta didik pada pendidikan RA adalah tercapainya tugas-tugas perkembangan secara optimal sesuai dengan standar yang dirumuskan.

Aspek-aspek perkembangan yang dirumuskan meliputi aspek moral dan nilai-nilai agama, sosial emosional, dan kemandirian, berbahasa, kognitif, fisik/motorik, dan seni. Salah satu kemampuan yang dirasa perlu dan penting di mulai pada usia dini adalah kemampuan berbahasa Inggris secara baik dan benar. Bahasa Inggris sangat diperlukan bagi mereka di masa mendatang ketika mereka menghadapi era globalisasi. Jika mereka mampu menguasainya dengan baik, niscaya mereka akan mampu berkompetensi dan berkembang dengan mumpuni.

Berdasarkan sejumlah pengamatan yang dilakukan, tim pelaksana memandang perlu memberikan kontribusi dalam hal pemberian masukan berupa pelatihan kepada guru bahasa Inggris di PAUD RA Bintang Sembilan mengenai metode pembelajaran MASAK (Mudah, Asyik, Santai, Aktif, Kreatif) sebagai metode pembelajaran bahasa Inggris untuk membantu meningkatkan penguasaan kosakata dan keterampilan mendengarkan bahasa Inggris. Metode pembelajaran MASAK (Mudah, Asyik, Santai, Aktif, Kreatif) merupakan salah satu cara yang kami gunakan untuk mrncapai tujuan pembelajaran tersebut agar tercapai. Teknik yang digunakan untuk pembelajaran bahasa Inggris untuk anak usia dini ada tiga, yaitu membacakan cerita (story telling), lagu (songs), dan permainan (games).

Hal ini dilakukan agar pembelajaran bahasa Inggris anak dirasakan oleh dapat sebagai pelajaran yang menyenangkan dan pelajaran yang menarik. Metode pembelajaran MASAK (Mudah, Asyik, Santai, Aktif, Kreatif) merupakan metode pembelajaran bahasa Inggris dalam bentuk permainan. Metode ini sangat mudah dan ringan dalam segi penggunaan bahasa dan juga mengandung unsur gerakan permainan sehingga dapat menghilangkan stres pada anak, dan juga dengan suasana hati yang positif dapat memfasilitasi pembelajaran sehingga dapat meningkatkan motivasi anak. Guru atau instruktur memiliki peran aktif dan langsung dalam menerapkan metode ini. Untuk memperbaiki dan meningkatkan kemampuan kosakata bahasa Inggris guru dan siswa maka kami ingin berbagi ilmu yang kami miliki dengan memberikan pelatihan dengan tema "Pelatihan Metode Pembelajaran MASAK (Mudah, Asyik, Santai, Aktif, Kreatif) Terhadap Penguasaan Kosakata dan Mendengarkan bahasa Inggris Guru PAUD RA Bintang Sembilan Cipayung Depok."

Metode pembelajaran merupakan hal signifikan dalam melaksanakan proses belajar. Pembelajaran sebaiknya dilaksanakan dengan cara menarik dan tidak 
menjenuhkan yang mampu membangkitkan ketertarikan siswa untuk melaksanakan proses pembelajaran.

Menurut Sutikno (2014: 33-34) metode secara harfiah berarti "cara". Metode diartikan sebagai suatu cara atau prosedur yang dipakai untuk mencapai tujuan tertentu. Kata "pembelajaran" berarti segala upaya yang dilakukan oleh pendidik agar terjadi proses belajar pada diri peserta didik. Jadi, metode pembelajaan adalah cara-cara menyajikan materi pelajaran yang dilakukan oleh pendidik agar terjadi proses belajar pada diri peserta didik dalam upaya untuk mencapai tujuan.

Senada dengan pendapat di atas, Hamzah dan Nurdin (2011: 7), menjabarkan metode pembelajaran sebagai cara yang digunakan guru dalam menjalankan fungsinya dan merupakan alat untuk mencapai tujuan pembelajaran. Metode pembelajaran yang digunakan sesuai dengan kebutuhan akan dapat menentukan keberhasilan dalam menyampaikan pembelajaran.

Komalasari (2010: 56) mendefinisikan metode pembelajaran sebagai cara yang dilakukan seseorang untuk menerapkan metode yang spesifik. Misalnya, penerapan metode ceramah pada kelas membutuhkan teknik tersendiri apalagi jika jumlah siswanya tidak sedikit, yang tentunya secara teknis akan berbeda dengan penggunaan metode ceramah pada kelas yang jumlah siswanya sedikit. Demikian juga sama halnya dengan metode diskusi, teknik yang berbeda perlu diterapkan pada kelas yang siswanya aktif dibandingkan dengan kelas yang siswanya cenderung pasif. Metode pembelajaran adalah cara konkret yang dipakai saat proses pembelajaran berlangsung. Guru dapat berganti-ganti teknik pembelajaran meskipun dalam koridor metode yang sama.

Berdasarkan pendapat ahli di atas, dapat disimpulkan bahwa metode pembelajaran adalah suatu upaya yang dilakukan seseorang dalam melaksanakan sebuah pembelajaran yang ditampilkan secara praktis. Tujuan pembelajaran dapat dicapai secara optimal dengan metode pembelajaan yang efektif, menyenangkan, dan menarik yang dapat membangkitkan minat siswa dalam proses belajar mengajar di kelas.

Kegiatan pengabdian kepada masyarakat ini difokuskan kepada Guru PAUD RA Bintang Sembilan Cipayung Depok. Model pembelajaran MASAK (Mudah, Asyik, Santai, Aktif, Kreatif) Terhadap Penguasaan Kosakata dan Mendengarkan bahasa Inggris yang diterapkan kepada Guru PAUD RA Bintang Sembilan Cipayung Depok, adalah cara yang efektif untuk mengembangkan keterampilan, pemahaman, sikap, dan ketertarikan siswa PAUD RA Bintang Sembilan dalam pelaksanaan pembelajaran.

\section{METODE PELAKSANAAN}

Dengan menerapkan metode MASAK (Mudah, Asyik, Santai, Aktif, Kreatif) terhadap anak-anak PAUD RA Bintang Sembilan, diharapkan mereka menyukai metode pembelajaran yang digunakan, sehingga proses pembelajaran berjalan dengan baik sehingga anak tidak merasa jenuh, bosan dan sulit untuk menguasai kosakata. Untuk mencapai tujuan yang telah ditetapkan, maka kegiatan pengabdian kepada masyarakat ini dilakukan dengan menggunakan langkah-langkah sebagai berikut:

1. Penyemaian informasi, berupa landasan teoretis tentang metode pembelajaran yang dapat digunakan dalam proses pembelajaran.

2. Pemberian contoh-contoh metode pembelajaran yang dapat digunakan dapat digunakan dalam pembelajaran kosakata dan menyimak, salah satunya adalah metode pembelajaran MASAK (Mudah, Asyik, Santai, Aktif, Kreatif). 
3. Mempraktikkan penggunaan metode pembelajaran MASAK (Mudah, Asyik, Santai, Aktif, Kreatif) dalam proses mengajarkan kosa kata dan menyimak Bahasa Inggris kepada anak.

4. Kegiatan pendampingan (monitoring) dilaksanakan dengan cara mengumpulkan para guru beserta peserta didik, kemudian memberikan repetition drill, dan yang terakhir adalah memonitor kegiatan mereka dalam mengaplikasikan metode pembelajaran MASAK (Mudah, Asyik, Santai, Aktif, Kreatif).

Pemberian pelatihan dilakukan oleh tim pengabdian masyarakat. Sementara itu, PAUD RA Bintang Sembilan Depok bertugas menyediakan sarana prasarana demi lancarnya kegiatan pelatihan seperti sumber listrik, tempat, meja dan kursi. Pelatihan dilaksanakan dengan pendekatan andragogi. Metode pembelajaran lebih banyak demonstrasi, tanya jawab dan praktik. Materi pelatihan disajikan dengan lebih banyak praktik daripada teori, dengan rasio perbandingan $30 \%$ teori dan $70 \%$ praktik.

\section{HASIL DAN PEMBAHASAN}

Pembelajaran bahasa pada anak usia dini harus dilakukan dengan menyenangkan dan dekat dengan keseharian anak. metode MASAK (Mudah, Asyik, Santai, Aktif, Kreatif) sangat memenuhi unsur tersebut. Metode MASAK (Mudah, Asyik, Santai, Aktif, Kreatif) merupakan metode pembelajaran bahasa Inggris dalam bentuk permainan. Metode ini sangat mudah dan ringan dalam segi penggunaan bahasa dan juga mengandung unsur gerakan permainan sehingga dapat menghilangkan stres pada anak, dan juga dengan suasana hati yang positif dapat memfasilitasi pembelajaran sehingga dapat meningkatkan motivasi anak. Guru atau instruktur memiliki peran aktif dan langsung dalam menerapkan metode ini. Media yang digunakan untuk mendukung penggunaan metode pembelajaran MASAK (Mudah, Asyik, Santai, Aktif, Kreatif) dalam pembelajaran kosakata dan menyimak bahasa Inggris adalah membacakan cerita (story telling), lagu (songs), dan permainan (games). Hal ini dilakukan agar pembelajaran bahasa Inggris anak dirasakan oleh dapat sebagai pelajaran yang menyenangkan dan pelajaran yang menarik.

Kegiatan Pengabdian Masyarakat ini dilaksanakan dalam dua tahap, yaitu tahap pelatihan dan monitoring. Kegiatan pelatihan dilaksanakan di PAUD RA Bintang Sembilan Depok. Pelatihan pertama ini memberikan teori dan mengenalkan metode pembelajaran dengan menggunakan metode pembelajaran MASAK (Mudah, Asyik, Santai, Aktif, Kreatif) kepada para guru PAUD RA Bintang Sembilan Depok. Tim pengabdian masyarakat mengajarkan kepada peserta bagaimana menerapkan metode pembelajaran interaktif dengan menggunakan metode pembelajaran MASAK (Mudah, Asyik, Santai, Aktif, Kreatif) ini pada anak. Setelah memahami penjelasan dari Tim, para guru mulai menggunakan metode pembelajaran MASAK (Mudah, Asyik, Santai, Aktif, Kreatif) dengan bantuan dan panduan oleh tim pengabdian masyarakat. Di tahap ini para guru mengetahui dan mempelajari bahwa dengan menggunakan metode pembelajaran MASAK (Mudah, Asyik, Santai, Aktif, Kreatif) pembelajaran bahasa Inggris dapat disiasati dengan berbagai cara - metode dan teknik serta permainan (games) maupun media pembelajaran - yang akan membuat anak tidak merasa sedang belajar tetapi sedang bermain, sehingga anak merasa asyik belajar Inggris. 
Kegiatan monitoring dilakukan dengan cara tim akan melihat kegiatan belajar mengajar dengan menggunakan metode pembelajaran MASAK (Mudah, Asyik, Santai, Aktif, Kreatif) PAUD RA Bintang Sembilan Depok. Berdasarkan wawancara yang dilakukan tim dengan guru PAUD RA Bintang Sembilan Depok, penggunaan metode MASAK (Mudah, Asyik, Santai, Aktif, Kreatif) kemampuan anak dalam kosakata dan mendengarkan meningkat dengan baik. Ada beberapa faktor yang menyebabkan peningkatan ini. (1) Faktor menyimak/ mendengarkan, anak yang tidak memiliki alasan kuat untuk menyimak/mendengarkan informasi yang disampaikan, sering kali mengalami kesulitan dalam memahami atau mencerna informasi tersebut. Di sinilah peran guru, untuk memberikan dorongan supaya anak mau menyimak/mendengarkan dengan diberikan reward atau hadiah bagi yang dapat memberikan feedback dengan benar. (2) Faktor situasi, lingkungan yang mendukung anak untuk menyimak atau mendengarkan, dengan kata lain, lingkungan yang jauh dari berbagai bunyi dan suara yang dapat mengganggu anak dalam mendengarkan. Dalam hal ini lingkungan PAUD RA Bintang Sembilan Depok jauh dari jalan raya utama, pabrik, pasar atau pusat keramaian sehingga bisa dikatakan lingkungan tersebut sangat mendukung anak untuk mendengarkan. (3) Faktor penutur atau guru yang menyampaikan pembelajaran dikelas merupakan guru dengan latar belakang pendidikan bahasa Inggris, sehingga ketepatan pengucapan beberapa vocabulary dilakukan dengan tepat. Hal ini membuat anak menjadi tertarik untuk mengikuti vocab yang diberikan guru di dalam kelas. Disamping itu, pengucapan vocabulary tadi diikuti dengan gerakan (gesture), ekpresi wajah, bahasa tubuh penutur dengan tepat. Hal ini menambah poin positif bagi pembelajaran anak. (4) Faktor teman sebaya, sebagaimana yang kita ketahui bahwa anak usia 4-5 tahun masih dalam tahap bermain asosiatif, di mana anak bermain bersama dengan kelompoknya atau temannya, apa yang dilakukan temannya maka akan dilakukannya. Sehingga pembelajaran bahasa Inggris dengan metode TPR dianggap oleh anak sebagai kesempatan bermain dengan teman temannya. Gabungan dari faktor-faktor tersebut memberikan kontribusi penggunaan metode MASAK (Mudah, Asyik, Santai, Aktif, Kreatif) dapat meningkatkan minat belajar anak dalam belajar bahasa Inggris.

Pembelajaran dengan menggunakan metode MASAK (Mudah, Asyik, Santai, Aktif, Kreatif) diharapkan dapat memberikan hasil dan manfaat pembelajaran yang diwujudkan ke dalam luaran (output) pembelajaran agar dapat digunakan khalayak ramai, dalam hal ini secara khusus terhadap dunia pendidikan dan pengajaran. Adapun luaran yang dapat dihasilkan dari kegiatan pembelajaran ini antara lain berupa buku ajar seperti penyusunan modul (workbook) untuk guru agar dapat memahami materi ajar secara lebih detail. Penyusunan modul dilakukan dalam rangka pemberian umpan balik tim pelaksana kepada guru terhadap kegiatan pembelajaran yang dilakukan dengan harapan dapat meningkatkan pemahaman kosakata untuk kemampuan mendengarkan bahasa Inggris anak. 


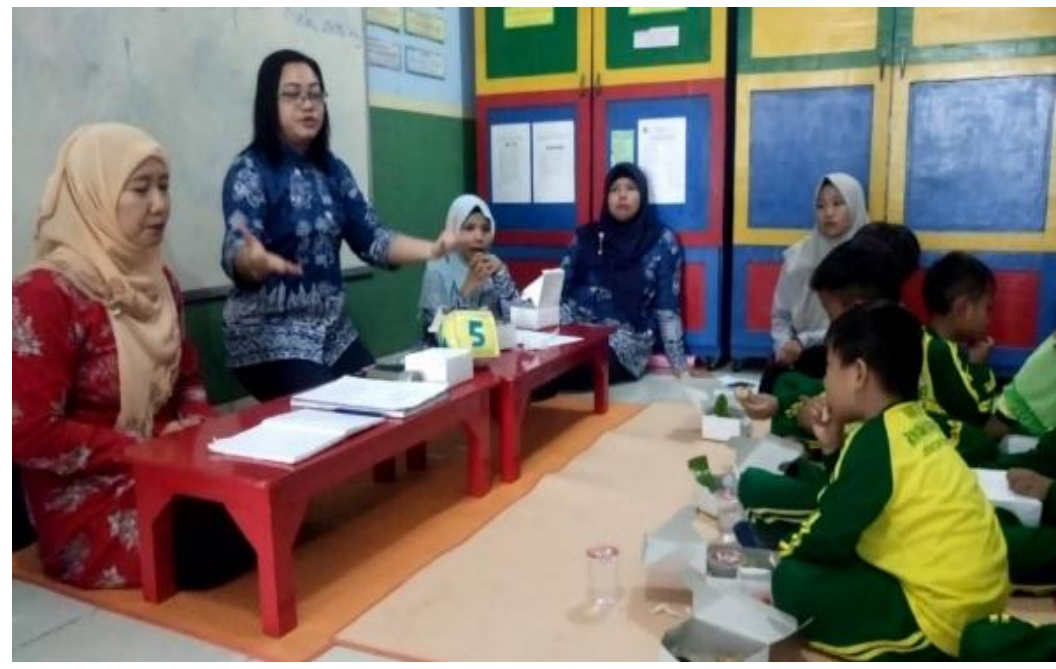

Gambar 1. Tim Abdimas Memperkenalkan Metode Pembelajaran MASAK (Story Telling)

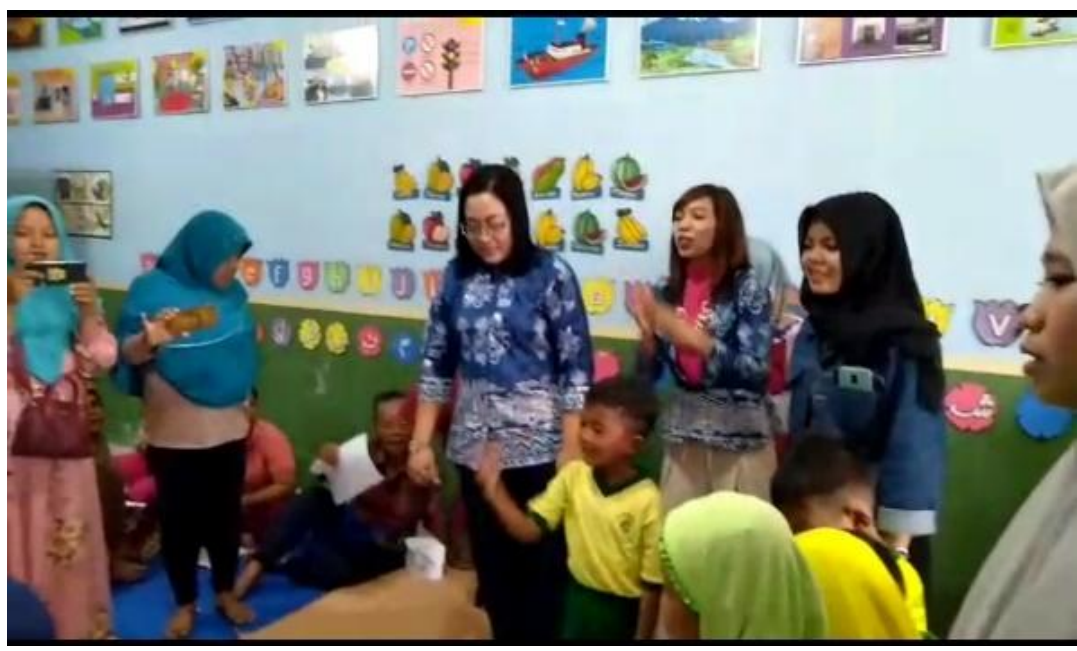

Gambar 4. Tim Abdimas Memperkenalkan Metode Pembelajaran MASAK (Guessing Colours)

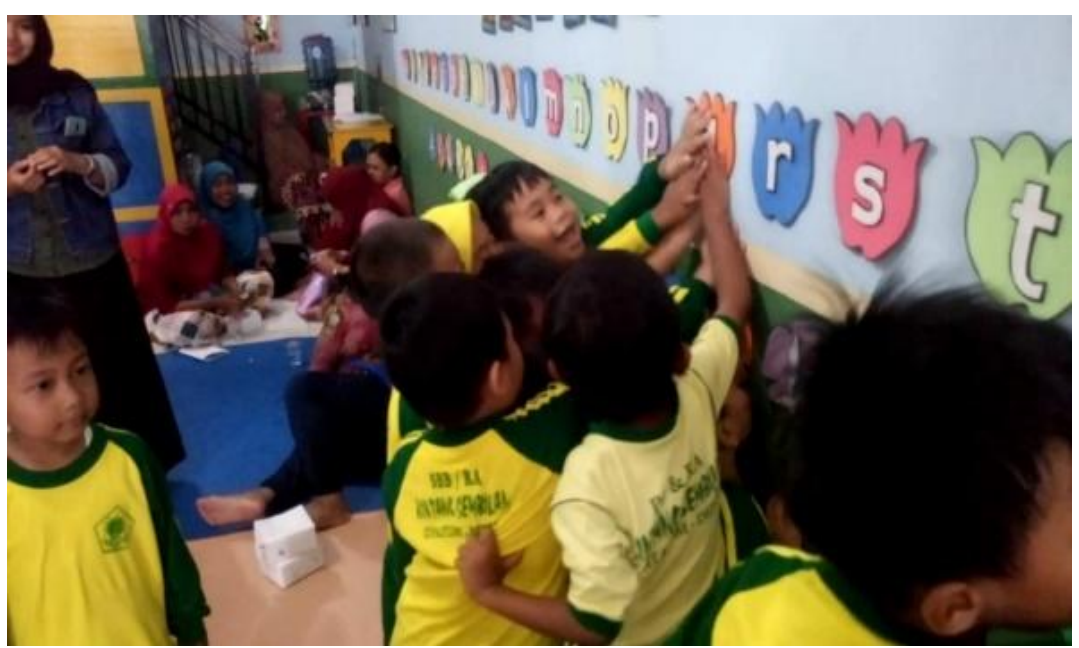

Gambar 4. Tim Abdimas Memperkenalkan Metode Pembelajaran MASAK (Guessing Colours) 


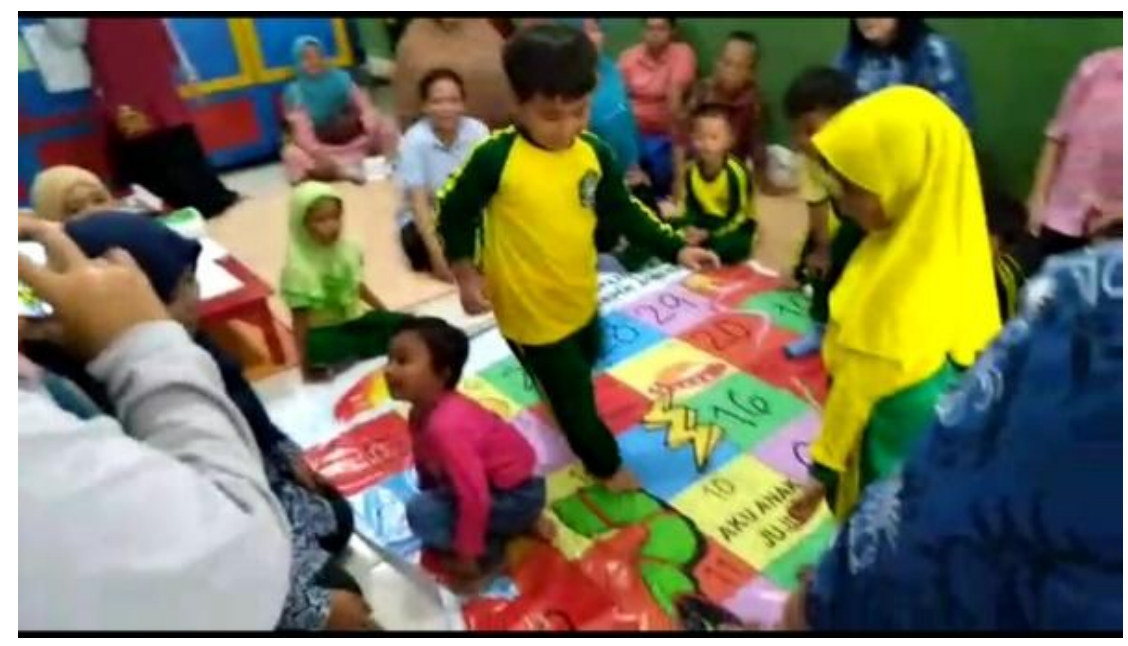

Gambar 4. Tim Abdimas Memperkenalkan Metode Pembelajaran MASAK (Guessing Colours)

\section{SIMPULAN}

Dari hasil pelaksanaan kegiatan pengabdian kepada masyarakat, diberikan beberapa kesimpulan sebagai berikut:

1. Metode MASAK (Mudah, Asyik, Santai, Aktif, Kreatif) merupakan salah satu metode yang tepat untuk digunakan dalam mengajarkan Bahasa Inggris, terutama kosakata dan mnyimak kepada anak dengan cara yang menyenangkan dan mudah.

2. Guru dapat memanfaatkan penggunaan metode MASAK (Mudah, Asyik, Santai, Aktif, Kreatif) dalam menyampaikan pembelajaran mengenai penguasaan kosakata bahasa Inggris.

3. Sekolah dapat memanfaatkan metode MASAK (Mudah, Asyik, Santai, Aktif, Kreatif) untuk menunjang pembelajaran sehingga dapat meningkatkan kualitas pembelajaran dan menghasilkan pembelajaran yang berkualitas.

\section{DAFTAR PUSTAKA}

Agustian, M. ( 2008). Perkembangan Ketrampilan Berbahasa Pada Anak Usia Dini. Jakarta: Kemendiknas: Dikti

Azim. 2002. Membimbing Anak Terampil Berbahasa. Jakarta : Gema Insani Press

B, Hamzah., \& Nurdin. (2011). Belajar dengan Pendekatan PAILKEM. Jakarta: Bumi Aksara.

Dardjowidjojo, K. (2004). Prinsip Prinsip Dasar Penelitian Bahasa dan Sastra. Bandung: Nuansa

Izdihar, Hasna. 2009. Pembelajaran Bahasa Kedua Melalui Immersion Programs Language Immersion. Fakultas Ekologi Manusia Institut Pertanian Bogor. 
Komalasari, Kokom. (2010). Pembelajaran Kontekstual (Konsep dan Aplikasi). Bandung: PT. Refika Aditama.

Martini, Jamaris. (2006). Perkembangan dan pengembangan anak usia taman kanakkanak. Jakarta: Grasindo.

Peraturan Menteri Pendidikan dan Kebudayaan Republik Indonesia Nomor 137 Tahun 2014 Tentang Standar Nasional Pendidikan Anak Usia Dini.

Rusefrinaria 2012. Peningkatan Kosa Kata Bahasa Inggris Anak Melalui Permainan Tebak Suara dengan Kartu Gambar Binatang di Paud Palapa I Kecamatan Batang Anai Kabupaten Padang Pariaman. E-journal.unp.ac.id, 1(1). Retrieved from http://ejournal.unp.ac.id/index.php/paud/article/view/1698

Sheppard, Philip. (2010). Music makes your child smarter (peran musik dalam perkembangan anak). Jakarta: Gramedia Pustaka

Sutikno, M. Sobry. (2014). Metode dan Model-model Pembelajaran. Lombok: Holistica.

Suyanto, Kasihani. (2012.) English for Young Learner. Jakarta: Bumi Aksara.

Undang-undang Nomor 20 Tahun 2003 tentang Sistem Pendidikan Nasional. 